\title{
Interdecadal variability of the Arabian Sea and the Indian Ocean
}

\author{
A. N. Zhukov ${ }^{1}$, N. E. Lebedev ${ }^{1}$, and A. M. Chukharev ${ }^{1}$ \\ Received 17 March 2016; accepted 30 March 2016; published 6 April 2016.
}

On the base of reanalysis data and station measurements during the last century, the spatial-temporal distribution of $\sim 60 \mathrm{yr}$ and other interdecadal oscillations for the part of hydrometeorological, hydrophysical and hydrobiological parameters of the Arabian Sea and the Indian Ocean was studied. Their dominant climate trends at present time are shown for the different parts of the region. We were also investigated periodicities in the time series of various marine and terrestrial paleo-reconstructions having duration up to 5000 yrs based of the study of marine sediments, coral reefs, dendrochronology, stalagmites, ice cores which are both from this region and the adjacent areas, as well as the Wolf number. The climatic variability of an Indian Ocean Dipole (IOD) index was analyzed. It has been shown that the $\sim 60$-yr oscillations play an important role in the variability of the monsoon over the Arabian Sea and the Indian Ocean. KEYWORDS: Monsoon of the Indian Ocean; Indian Ocean Dipole; reanalysis and station measurement data; paleoreconstructions; interdecadal variability; $\sim 60$ yr oscillations.

Citation: Zhukov, A. N., N. E. Lebedev, and A. M. Chukharev (2016), Interdecadal variability of the Arabian Sea and the Indian Ocean, Russ. J. Earth. Sci., 16, ES2001, doi:10.2205/2016ES000565.

\section{Introduction}

The Arabian Sea is influenced by the Asian monsoon, which consists of the Indian and East Asian subsystems (Figure 1) [Wang et al., 2005. One of the parts of the East Asian subsystem is the Russian Far East. These subsystems have many similarities in interdecadal variability, while Indian one is more provided with observational data.

The dynamics of the Arabian Sea is significantly affected by monsoon circulation of the northern Indian Ocean. Although studies of this region were held for a long time [Sverdrup et al., 1942, but at present, due to the high seasonal variation and a small amount of contact data, differences in estimations of climatic trends of its meteorological parameters are still remain.

Direct relation to the monsoon circulation mechanism has the phenomenon of the Indian Ocean Dipole (IOD). Positive IOD index phase is corresponding with positive anomalies of surface temperature and precipitation in the west of the Indian Ocean and negative anomalies in the east, with rainfalls in eastern Africa and drought in Indonesia and Australia. During the negative phase of the IOD situation is reversed [Li et al., 2003. Studies of fossil coral reefs indicate that the IOD is operating at least for 6500 yrs [Abram et al., 2007].

\footnotetext{
${ }^{1}$ Marine Hydrophysical Institute, Russian Academy of Sciences, Sevastopol, Russia

Copyright 2016 by the Geophysical Center RAS.

http://elpub.wdcb.ru/journals/rjes/doi/2016ES000565-res.html
}

In general, the IOD is one of the manifestations of global climate cycles such as El Niño - Southern Oscillation (ENSO) in the Pacific Ocean [Byshev et al., 2012 Rao et al., 2002.

It was concluded [Eremeev et al.,2012a that climatic factors which change monsoon circulation mode and the associated productivity of the Arabian Sea, are due to the processes developing in the scales of $5000-8000 \mathrm{~km}$ which are significantly exceed the sea dimensions, and at time intervals that are comparable with 60 yrs. Also there were made assumptions that:

- a major role in the variability of monsoon circulation regime on centennial scale plays a $\sim 60$ yr oscillations of atmospheric pressure and water temperature;

- in the coming years its positive half period seems to be replaced by a negative, which will result in changing of the IOD index phase onto the negative.

The fundamental importance of $\sim 60 \mathrm{yr}$ oscillations in the interdecadal variability of these parameters, as well as their possible relation with solar activity, is noted in [Goswami et al., 2006 Klyashtorin and Lyubushin, 2007. Loehle and Scafetta, 2011. Mehta and Lau, 1997. Pokrovsky, 2010. But peculiar properties of the spatial-temporal manifestation of these oscillations for particular regions, including the monsoon region, are studied insufficiently [Agnihotri et al., 2002 Goswami, 2004. In the range of 40-100 yrs there is also known manifestation of other oscillations, e.g. with periods of $\sim 40,70,80-90$ yrs (Gleissberg cycle) [Schlesinger and Ramankutty, 1994 Tsiropoula, 2003. 


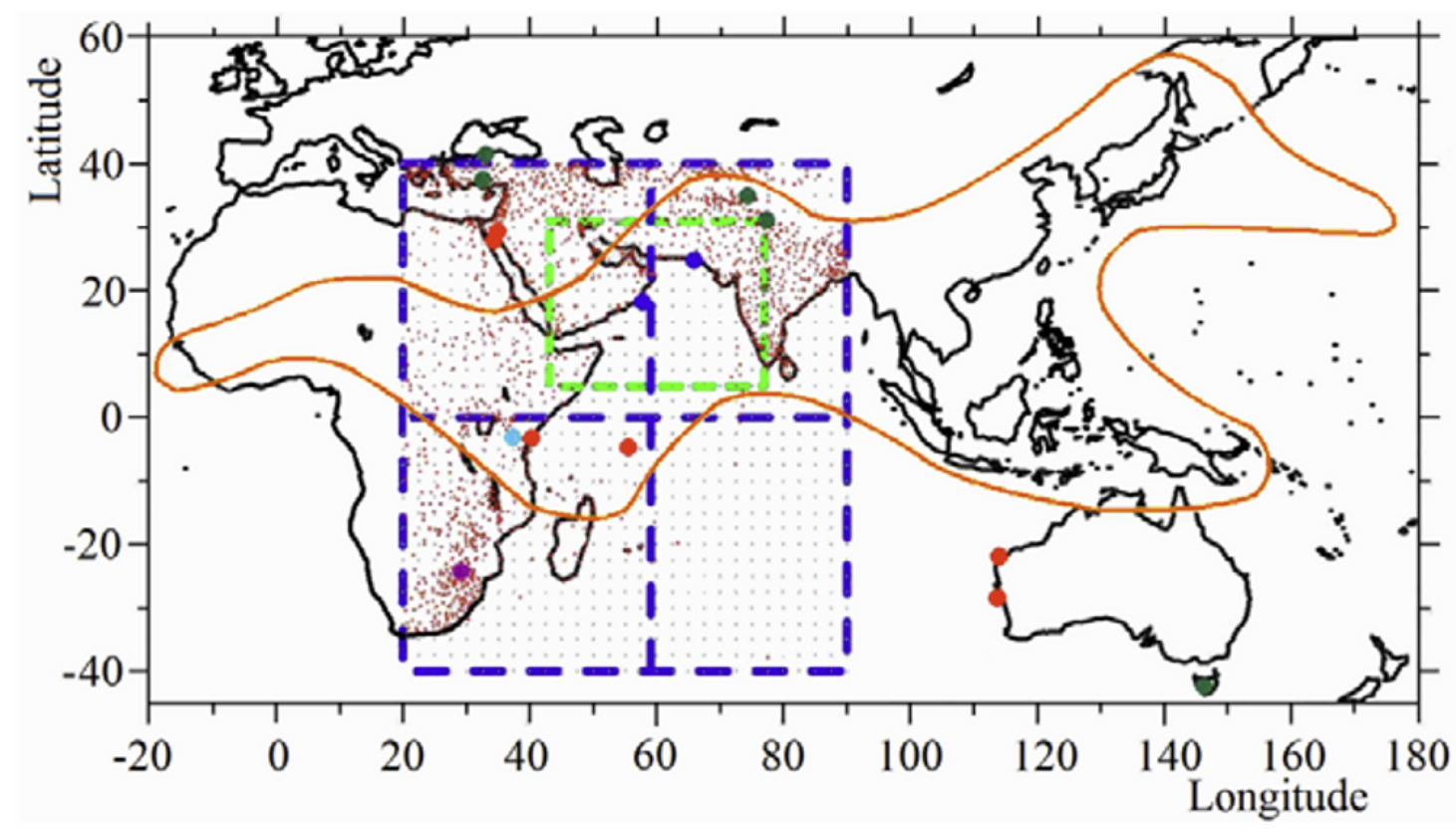

Figure 1. Locations of the NCDC weather stations (red dots), of the grid nodes of the $P$ reanalysis data upon Indian Ocean (gray dots) and of paleoreconstructions stations which data were used: of coral reefs (red circles), bottom sediments (blue), dendrochronology (dark green), ice cores (cyan), stalagmites (purple). The monsoon region in Asia, Africa and Australia is lined by orange contour. The regions under investigation in this paper are contoured by cyan dashed lines. The region under investigation in [Eremeev et al., 2012a] is contoured by green dashed lines.

The few works investigating the interdecadal variability in this region, are mainly related to the temporary reconstruction of variations of hydro-biological characteristics, for example, the number of sardines and anchovies upon the analysis of squama in the sediment columns [Baumgartner et al., 1992. Partly this is a consequence of insufficient length of the available series of station observations [Klyashtorin and Lyubushin, 2007 Pokrovsky, 2010. In cases when more longer paleoreconstruction series were studied, attention was usually paid to oscillations with periods of 100 yrs or more for the studying of solar-terrestrial and other external links in the framework of astronomical cycles [Agnihotri et al., 2002 Berger and von Rad, 2002 Buehring, 2001 Scafetta, 2010 Wang et al., 2005.

In view of the above, the aim of this work is to study the spatial and temporal manifestation and stability of the $\sim 60 \mathrm{yr}$ and other long-period oscillations of basic meteorological parameters in the region of the Arabian Sea and the Indian Ocean.

\section{Data and Methods}

To this study we involved the most extensive time series of the reanalysis and station measurement data of the atmosphere and hydrosphere: the near-surface temperatures of air SAT and water $\operatorname{SST}\left({ }^{\circ} \mathrm{C}\right)$, atmospheric pressure $P(\mathrm{hPa})$ and the water vapor pressure $P_{\mathrm{wv}}(\mathrm{hPa})$, precipitation $\operatorname{Pr}(\mathrm{mm})$, sea level $\mathrm{SSH}(\mathrm{mm})$, wind speed $W(\mathrm{~m} / \mathrm{s})$. Reanalysis data of monthly $P$ values for 1949-2010 on $2.5^{\circ}$ grid were taken from (http://index-of/ pub/reanalysis-1/month/grb2d.lola/); SAT for the 19482007 and SST for the $1948-2010$ on $1.9^{\circ}$ grid; $W$ for the $1948-2010$ on $2.5^{\circ}$ grid from the NCEP/NCAR database (http://www.esrl.noaa.gov/psd/data/reanalysis/ reanalysis.shtml); $\operatorname{Pr}$ for the 1901-2009 on $2.5^{\circ}$ grid from the GPCC database (http://gpcc.dwd.de) [Schneider et al., 2010. Monthly data of station measurements $P$, SAT, $P_{\mathrm{wv}}, \operatorname{Pr}$ were taken from the NCDC database (http://rda.ucar.edu/datasets/ds570.0/), and SSH from the PSMSL database (http://www.psmsl.org/).

Based on the results obtained in [Eremeev et al., 2012a, the fragment within $40^{\circ} \mathrm{N}-40^{\circ} \mathrm{S}, 20^{\circ}-90^{\circ} \mathrm{E}$ was chosen for studying (Figure 1). The green dashed line shows the area under analysis in [Eremeev et al.,2012a]. To reveal the spatial features of the reanalysis parameters, this fragment was divided into quarters where the spatial averaging of these parameters was performed: the Northwest (NW), Northeast (NE), Southwest (SW) and the Southeast(SE) separated by crossed lines along $0^{\circ} \mathrm{N}$ and $59^{\circ}$ E. The latter value is a compromise between the location of the geometric center of the whole fragment and the geographic location of features of investigated parameters.

Since the duration of the reanalysis series does not exceed 63 yrs and the most extensive station observations series do not exceed 120-130 yrs, so to obtain the results for a longer time series, the data of various paleoreconstructions were 
Table 1. The Paleoreconstructions Data Used in This Work

\begin{tabular}{|c|c|c|c|c|}
\hline Objects & Data type & Region & Time range & Data source \\
\hline Coral reefs & $\delta^{18} \mathrm{O}, \%$ & $\begin{array}{c}\text { Kenya, Malindi } \\
3.2^{\circ} \mathrm{S}, 40.2^{\circ} \mathrm{E}\end{array}$ & $\begin{array}{l}1801-1994 \\
\text { (194 years) }\end{array}$ & $\mathrm{WDC}^{(1)}$ \\
\hline Coral reefs & $\delta^{18} \mathrm{O}, \%$ & $\begin{array}{c}\text { Seychelles, Mahe island } \\
4.7^{\circ} \mathrm{S}, 55.5^{\circ} \mathrm{E}\end{array}$ & $\begin{array}{l}1847-1994 \\
(148 \text { years })\end{array}$ & $\mathrm{WDC}^{-\mathrm{A}^{(1)}}$ \\
\hline Coral reefs & $\delta^{13} \mathrm{C}, \%, \delta^{18} \mathrm{O}, \%$ & $\begin{array}{l}\text { Australia, Ningaloo } \\
21.91^{\circ} \mathrm{S}, 113.97^{\circ} \mathrm{E}\end{array}$ & $\begin{array}{l}1878-1994 \\
(116 \text { years })\end{array}$ & $\mathrm{WDC}^{-\mathrm{A}^{(1)}}$ \\
\hline Coral reefs & $\delta^{13} \mathrm{C}, \%$ oo, $\delta^{18} \mathrm{O}, \%$ & $\begin{array}{c}\text { Australia, Abrolhos islands } \\
28.46^{\circ} \mathrm{S}, 113.77^{\circ} \mathrm{E}\end{array}$ & $\begin{array}{l}1794-1993 \\
(200 \text { years })\end{array}$ & $\mathrm{WDC}^{-\mathrm{A}^{(1)}}$ \\
\hline Coral reefs & $\delta^{18} \mathrm{O}, \%$ & $\begin{array}{c}\text { Jordan, Aqaba } \\
29.43^{\circ} \mathrm{N}, 34.97^{\circ} \mathrm{E}\end{array}$ & $\begin{array}{l}1788-1992 \\
(206 \text { years })\end{array}$ & WDC-A ${ }^{(1)}$ \\
\hline Coral reefs & $\delta^{18} \mathrm{O}, \%$ & $\begin{array}{l}\text { Egypt, Ras Umm Sidd } \\
27.85^{\circ} \mathrm{N}, 34.31^{\circ} \mathrm{E}\end{array}$ & $\begin{array}{l}1751-1995 \\
(245 \text { years })\end{array}$ & $\mathrm{WDC}^{(1)}$ \\
\hline Bottom sediments & G. bulloides (\%) & $\begin{array}{c}\text { Oman } \\
18.23^{\circ} \mathrm{N}, 57.67^{\circ} \mathrm{E}\end{array}$ & $\begin{array}{l}1053-1993 \\
(950 \text { years })\end{array}$ & (2) \\
\hline Bottom sediments & Varve thickness (mm) & $\begin{array}{l}\text { Pakistan, Karachi } \\
24.83^{\circ} \mathrm{N}, 65.92^{\circ} \mathrm{E}\end{array}$ & $\begin{array}{c}-50-1994 \\
(2043 \text { years })\end{array}$ & [Berger and von Rad, 2002 \\
\hline Dendrochronology & Total ring width $(\mathrm{mm})$ & $\begin{array}{l}\text { India, Himachal Pradesh } \\
\quad 31.2^{\circ} \mathrm{N}, 77.23^{\circ} \mathrm{E}\end{array}$ & $\begin{array}{l}1590-1989 \\
(400 \text { years })\end{array}$ & WDC-A ${ }^{(3)}$ \\
\hline Dendrochronology & Total ring width $(\mathrm{mm})$ & $\begin{array}{c}\text { Turkey, Alanya-Cevizli } \\
37.5^{\circ} \mathrm{N}, 32.5^{\circ} \mathrm{E}\end{array}$ & $\begin{array}{l}1567-1995 \\
(429 \text { years })\end{array}$ & WDC-A ${ }^{(3)}$ \\
\hline Dendrochronology & Total ring width $(\mathrm{mm})$ & $\begin{array}{c}\text { Turkey, Pinarbasi } \\
41.5^{\circ} \mathrm{N}, 33.0^{\circ} \mathrm{E}\end{array}$ & $\begin{array}{l}1607-2001 \\
(395 \text { years })\end{array}$ & WDC-A ${ }^{(3)}$ \\
\hline Dendrochronology & Total ring width $(\mathrm{mm})$ & $\begin{array}{c}\text { Australia, Tasmania } \\
42.39^{\circ} \mathrm{S}, 146.34^{\circ} \mathrm{E}\end{array}$ & $\begin{array}{l}1028-1975 \\
(948 \text { years })\end{array}$ & $\begin{array}{l}\text { Time Series Data Library by } \\
\text { R. Hyndman and M. Akram }{ }^{(4)}\end{array}$ \\
\hline Dendrochronology & Total ring width $(\mathrm{mm})$ & $\begin{array}{c}\text { India, Kashmir } \\
35.08^{\circ} \mathrm{N}, 74.3^{\circ} \mathrm{E}\end{array}$ & $\begin{array}{l}1604-1980 \\
(377 \text { years })\end{array}$ & $\begin{array}{l}\text { Time Series Data Library by } \\
\text { R. Hyndman and M. Akram }\end{array}$ \\
\hline Ice core & $\delta^{18} \mathrm{O}, \%$ & $\begin{array}{c}\text { Tanzania, Mt. Kilimanjaro } \\
3.07^{\circ} \mathrm{S}, 37.35^{\circ} \mathrm{E}\end{array}$ & $\begin{array}{c}460-1950 \\
(1500 \text { years })\end{array}$ & NOAA Paleoclimatology ${ }^{(5)}$ \\
\hline $\begin{array}{l}\text { Speleothem stable } \\
\text { isotope data from an } \\
\text { aragonite stalagmite }\end{array}$ & $\begin{array}{l}\delta^{13} \mathrm{C}, \% \\
\delta^{18} \mathrm{O}, \%\end{array}$ & $\begin{array}{c}\text { South Africa, } \\
\text { Makapansgat Valley } \\
24.20^{\circ} \mathrm{S}, 29.20^{\circ} \mathrm{E}\end{array}$ & $\begin{array}{c}1-1996 \\
(1996 \text { years })\end{array}$ & $\mathrm{WDC}^{(1)}$ \\
\hline
\end{tabular}

Note: URL data sources mentioned in the table:

(1) http://www.ncdc.noaa.gov/paleo/coral/malindi.html

(2) ftp://ftp.ncdc.noaa.gov/pub/data/paleo/contributions_by_author/anderson2002/anderson2002.txt

(3) https://www.ncdc.noaa.gov/cdo/f?p=519:1:0:::P1_STUDY_ID:2796

(4) https://datamarket.com/data/list/?q=cat:ecw\%20provider:tsdl

(5) http://www.ncdc.noaa.gov/data-access/paleoclimatology-data/datasets/ice-core

used. To perform a more complete analysis, paleoreconstructions data of area adjacent to selected fragment also were involved. In total, involved paleoreconstructions present Turkey, west and Northeastof the Arabian Sea, Northwest of the Red Sea, Seychelles, Kenyan coast, Tanzania, South Africa, Pakistan shelf, northern India and Himalayas, western Australian coast, Tasmania (Figure 1, Table 1.

To study the temporal variability of meteorological parameters on the reanalysis data and station measurements, their representation in the form of annually averaged series was chosen (that is enough for studying their behavior on interdecadal scale [Hartmann, 1994] Klyashtorin and Lyubushin, 2007). In this case the meanings of summer monsoon as a more powerful phenomenon prevail in averaged values [Neiman et al., 1997], http://oceanworld.tamu.edu/ resources/ocng_textbook/PDF_files/book.pdf). Paleorecon- structions were presented in the form of decadal averaged series.

Searching for dominant oscillations of investigated parameters was performed by means of Fourier transform or wavelet analysis [Vityazev, 2001, while their selection from the original series was made by means of moving average filters (MAF) and bandpass MAF (BMAF) [Hamming, 1983].

\section{Results}

The results of wavelet analysis of IOD index values for the 1870-2015 [Rayner et al., 2003] (http://www.jamstec.go.jp/ frcgc/research/d1/iod/DATA/dmi.monthly.txt) are shown in Figure 2 As a parent was used Morlet wavelet, as it is closer to the harmonic oscillations [Vityazev, 2001]. 


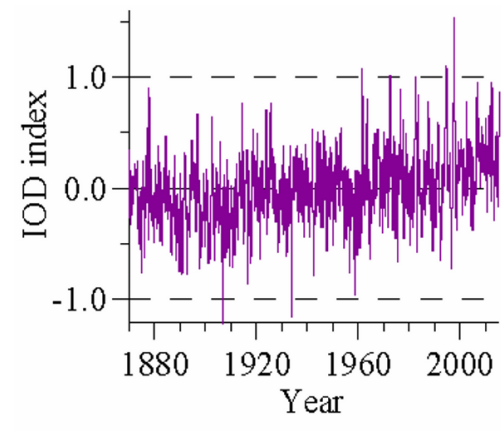

(a)

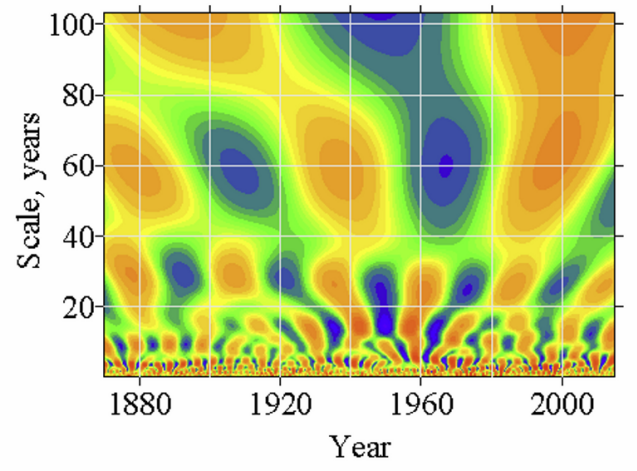

(b)

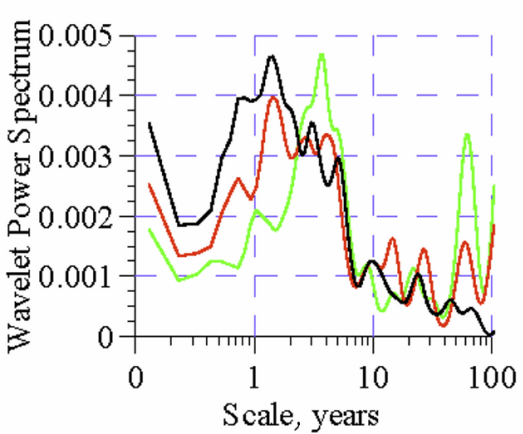

(c)

Figure 2. (a) the IOD index, (b) its wavelet transform (WT), (c) its wavelet global spectrum (black curve) and the wavelet global spectra of temperature anomalies which difference produces IOD index in the west of central part of the Indian Ocean (green) and in the east (red).

The wavelet global spectrum of IOD index Figure 2., black curve) shows existence of oscillations with periods close to $67,44,23,10,5,3$ and $1.4 \mathrm{yrs}$, while short-period (5 yrs or less) ones have a more large amplitude. For comparison, here also are presented the global spectra of temperature anomalies in the west of central part of the Indian Ocean (green) and in the east (red). IOD index is equal to difference of these anomalies. As can be seen, ratios of their shortperiod to long-period amplitudes are less than that of IOD index. This can be explained by that long-period oscillations of western and eastern parts of the Indian Ocean are better correlated with each other than the short-period ones. On the west the most pronounced oscillations have periods of 60 and 3 yrs.

IOD index components with periods of $\sim 67,44,23,10$ yrs represent in total a quasi-regular curve, which extrapolation, taking into account the general trend, is closest to the time axis without crossing it at about 2026. But a large contribution of short-period oscillations, along with variations of their amplitudes and periods, does not allow to predict in details the behavior of IOD index in the near future. One can only assume that under the present character of its trend, the negative phase of the IOD index at the interannual scale will come not earlier than in 2026.

The reanalysis and NCDC station observation series were filtered by MAFs sequence with windows of 20-30 and $10 \mathrm{yrs}$; PSMSL SSH series - by MAFs sequence with windows $\sim 2 / 3$ of the length of the series and 12 yrs. To extract the oscillations that are close to $\sim 60 \mathrm{yr}, \mathrm{BMAF}$ with $50-70$ yrs band was used.

Figure 3 shows the curves of reanalysis filtered series, averaged over the quarters of the test fragment. The results do not contradict the assumption that the main role in the low-frequency parts of the spectra of the studied parameters belongs to the half-periods of quasi-periodic oscillations lasting for $\sim 60-70$ yrs; more definite statement is not possible here because of the short duration of the reanalysis series. As it is seen, the phases and periods of the series for the various parameters and the fragment quarters are differ markedly.
All the $P$ curves are about half-periods of $\sim 60 \mathrm{yr}$ oscillation. Over the ocean its maximum and minimum have time offset with respect to the land in the east about 5-7 yrs backward, and in the west - forward. Note that at the interannual scale $P$ values change oppositely to its intra-annual run - in warm interannual periods (as if in "summer") they grow, while in cool interannual periods (as if in "winter") they fall.

The filtered SAT and SST series have the similar behavior (Figure 3, Figure 3 $\mathrm{d}$ ). As in case of $P$, here a minimum in the 1960s and a maximum in the 1990s is observed too. At that, phases of SAT curves of the southern quarters are ahead of northern, while phases of SST curves of the southern quarters are behind of northern. This figure shows also that on both SAT and SST curves, as well as on $W$ Figure $3 \mathrm{p}$ ) and $\operatorname{Pr}$ (Figure 3e) curves, oscillations with periods of about 20-30 yrs are also present.

Spectral analysis has shown that these curves along with $\mathrm{a} \sim 60$ yr harmonic, also include another three groups of harmonics with periods about $\sim 20-30,10-15$ and $3-5$ yrs. The most commonly expressed is the first group ( $\sim 20-30 \mathrm{yrs})$. For $P$ influence of the third group (3-5 yrs) is significant only on the south-eastern quadrant. In the spectra of the SST and SAT series, in contrary, the contribution of this group of harmonics is comparable to the amplitudes of multidecadal harmonics for all quarters. For $W$, amplitudes of $\sim 30 \mathrm{yr}$ harmonics are close to the amplitudes of $\sim 60 \mathrm{yr}$ harmonic or (on the south-east) exceed it.

Spectra of more longer $\operatorname{Pr}$ reanalysis series have another behavior. The amplitudes of their harmonics with periods $<20$ yrs in the western quarters exceed the amplitudes of $\sim 60$ yr harmonics for 1.5-2 times, and in the northeast this excess reaches more than 5 times. The original $\mathrm{Pr}$ data on the south-east are absent.

$\operatorname{Pr}$ varies in all quarters similarly to other parameters, but with a noticeable phase shift. In the Southwest, it is close to $\pi / 2$.

Figure $4 \mathrm{a}$ shows the curves of the filtered $P$ series for three stations - Lahore (Pakistan, $31.6^{\circ} \mathrm{N}, 74.3^{\circ} \mathrm{E}, 1941-$ 2007), Corfu (Greece, $\left.39.6^{\circ} \mathrm{N}, 19.9^{\circ} \mathrm{E}, 1951-2007\right)$ and Dur- 

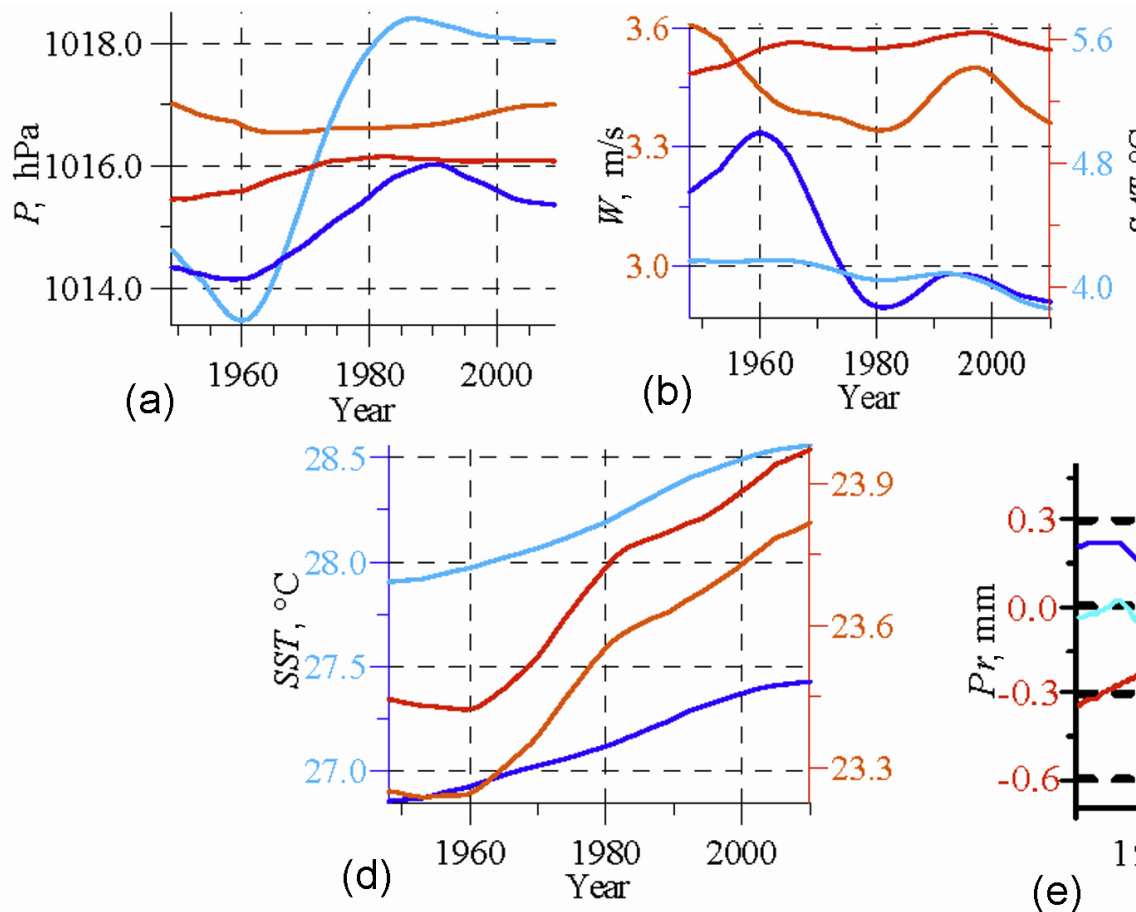

(d)
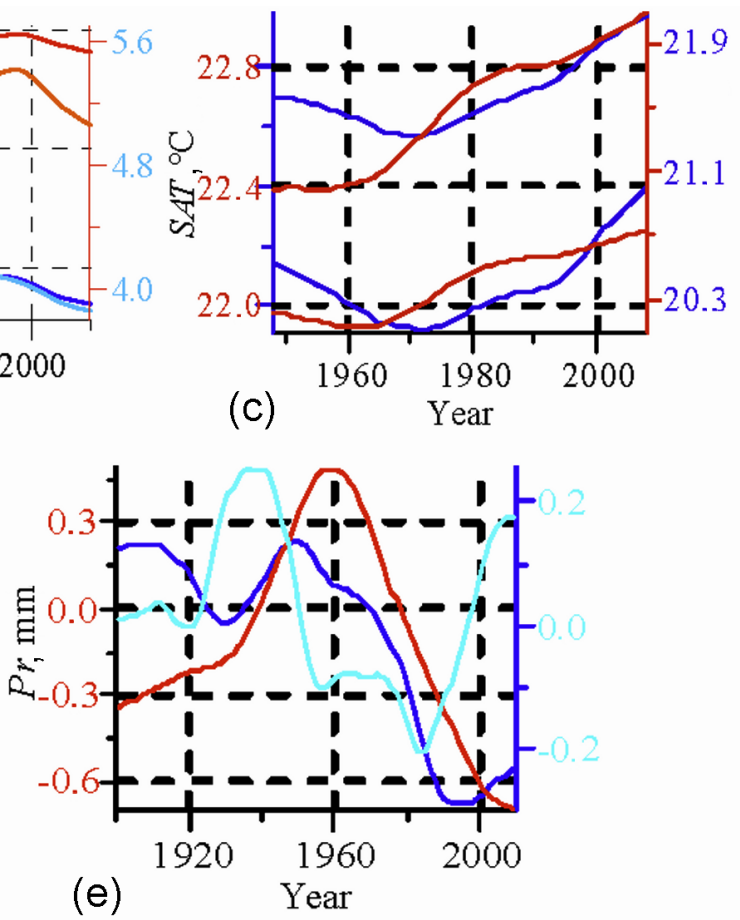

Figure 3. Multidecadal components of annually averaged reanalysis series of parameters: (a) $P$, (b) $W$, (c) SAT, (d) SST, (e) $\operatorname{Pr}$ for the Northwest (blue lines), the Northeast (cyan), Southwest (orange) and the Southeast (red) quarters.
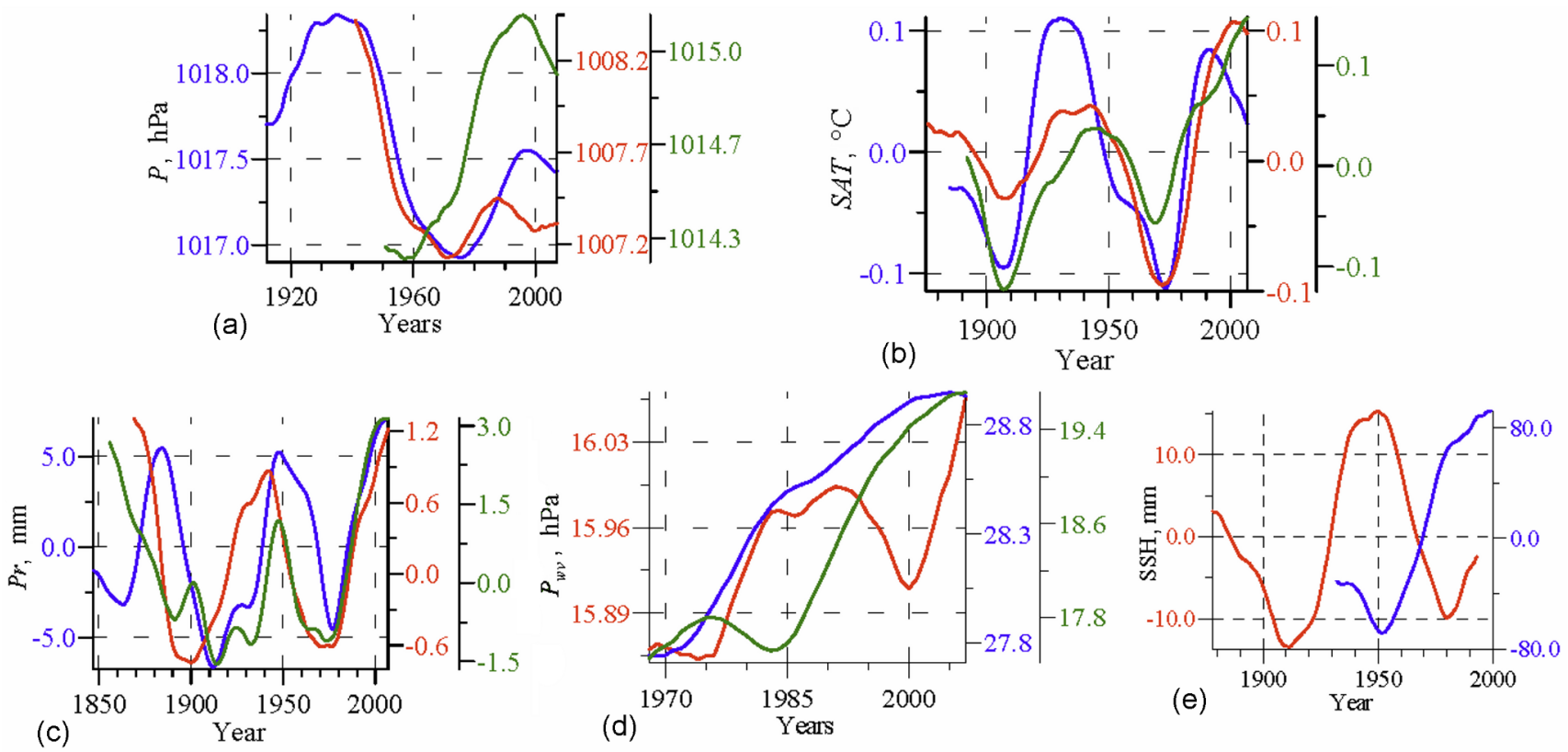

Figure 4. Multidecadal components of annually averaged values of station series: (a) $P$ for Lahore (red line), Corfu (green) and Durban (blue), (b) SAT for Port Elizabeth (blue), Lahore (red) and Thiruvananthapuram (green), (c) $P r$ for Ahmadabad (red), Mumbai (blue) and Pune (green), (d) $P_{\mathrm{wv}}$ for Indore (red), Thiruvananthapuram (blue), Jacobabad (green), (e) SSH for Mumbai (red), Calcutta (blue). 

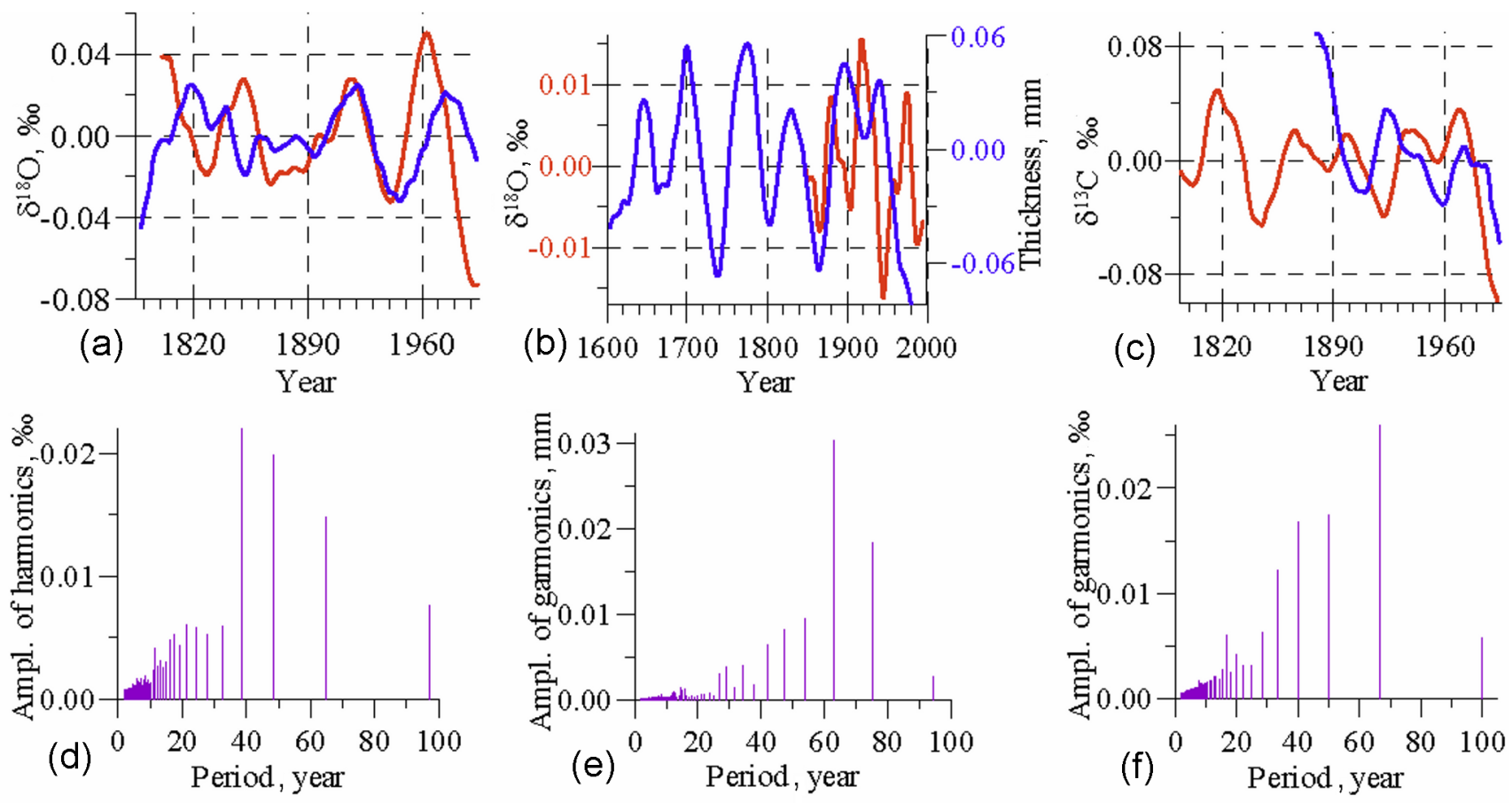

Figure 5. Multidecadal components of filtered paleoreconstructions series: (a) $\delta^{18} \mathrm{O}$ content in coral reefs in Malindi (red curves) and Aqaba (blue), (b) $\delta^{18} \mathrm{O}$ in the Mahe island (red) and the tree's annual rings in Kashmir (blue), (c) $\delta^{13} \mathrm{C}$ in the Abrolhos reefs (red) and Ningaloo reefs (blue); their spectra: (d) Malindi, (e) Kashmir, (f) Abrolhos.

ban (South Africa, $\left.29.9^{\circ} \mathrm{S}, 30.9^{\circ} \mathrm{E}, 1912-2007\right)$. For Durban in Figure 4a is visible expressed fragment of $\sim 60 \mathrm{yr}$ oscillation with duration a few more than its period. Curves of shorter series for Lahore are close to this fragment, too.

Curves of SAT series of station measurements filtered by BMAF with 50-70 yrs band in Port Elizabeth (South Africa, $\left.34.0^{\circ} \mathrm{S}, 25.6^{\circ} \mathrm{E}, 1885-2007\right)$, Lahore (1876-2007) and Thiruvananthapuram (India, $8.5^{\circ} \mathrm{N}, 77.0^{\circ} \mathrm{E}, 1892-2007$ ) are shown in Figure $4 \mathrm{~b}$. Small values of their amplitudes are due to the smoothing properties of BMAF which reduces the amplitude of the original signal for several times [Hamming, 1983].

Curves of $\mathrm{Pr}$ series filtered by BMAF with 50-70 yrs band for three Indian stations - Ahmedabad $\left(23.0^{\circ} \mathrm{N}, 72.6^{\circ} \mathrm{E}\right.$, 1869-2007), Mumbai (18.9 $\left.{ }^{\circ} \mathrm{N}, 72.8^{\circ} \mathrm{E}, 1847-2007\right)$ and Pune $\left(18.5^{\circ} \mathrm{N}, 73.9^{\circ} \mathrm{E}, 1856-2007\right)$ - are presented in Figure 4 . In a Pune series, as well as in Figure 3 there is noticeable the influence of oscillation with period of $\sim 25-30 \mathrm{yrs}$.

Curves of the $P_{\mathrm{wv}}$ filtered series for Indian stations Indore $\left(22.7^{\circ} \mathrm{N}, 75.8^{\circ} \mathrm{E}, 1968-2007\right)$, Thiruvananthapuram (19682007), and for Jacobabad (Pakistan, $28.3^{\circ} \mathrm{N}, 68.46^{\circ} \mathrm{E}, 1968$ 2007 yrs) are shown in Figure 4 d. They can be interpreted with caution as fragments of $\sim 60 \mathrm{yr}$ oscillations, since for the full its identification the lengths of these series are not enough. The curves for Jacobabad and Indore, as in Figure 4, contain noticeable oscillations with periods of $\sim 13$ yrs.

Curves of filtered series of annually averaged SSH values for Mumbai and Calcutta stations $\left(18.9^{\circ} \mathrm{N}, 72.8^{\circ} \mathrm{E}, 1878\right.$ 1993 and $\left.22.6^{\circ} \mathrm{N}, 88.3^{\circ} \mathrm{E}, 1932-1999\right)$ are shown in Figure $4 \mathrm{~d}$.
In general, they also represent the oscillations with periods of $\sim 60-80$ yrs.

Generalization of the results obtained for the most part of the tested region of the Indian Ocean (Figure 1 showed that the $\sim 60 \mathrm{yr}$ oscillation is one of the dominants in the spectra of the majority of the studied parameters. Along with it, there are also included harmonics with periods of $\sim 9-15$ and $20-25$ yrs.

Examples of paleoclimatic series filtered by BMAF with 50-70 yrs band are shown in Figure 5a, Figure 5b, Figure 5. Their spectra in the neighborhood of $\sim 60 \mathrm{yr}$ oscillations are shown in Figure 5d, Figure 5e, Figure 5:. As it is seen, here there are not one or two, but a group of interannual oscillations with close periods.

Figure 6 6 shows multidecadal oscillations derived from a series of the Australian tree's annual rings (from Time Series Data Library by R. Hyndman and M. Akram) by sequence of BMAFs with 40-700 and 80-400 yrs bands and the MAF with a 20 yrs window.

Its spectrum (Figure 6 $)$, in addition to oscillations with a period of $\sim 60-70$ yrs, have a well expressed $\sim 95$ yr harmonic, close to Gleissberg cycle. Figure $6 \mathrm{p}$, Figure $6 \mathrm{~d}$ shows multidecadal oscillations derived from a series of Mt. Kilimanjaro glacier by BMAF with 30-100 yrs band and their spectrum. Significant amplitude modulations of the oscillations (Figure 6c, Figure 6 d) are caused by the presence of closely spaced harmonics with similar amplitudes. Following the terminology of [Lobanov and Leonov, 1990, Monin and Sonechkin, 2005, these series, as well as many other climatic 

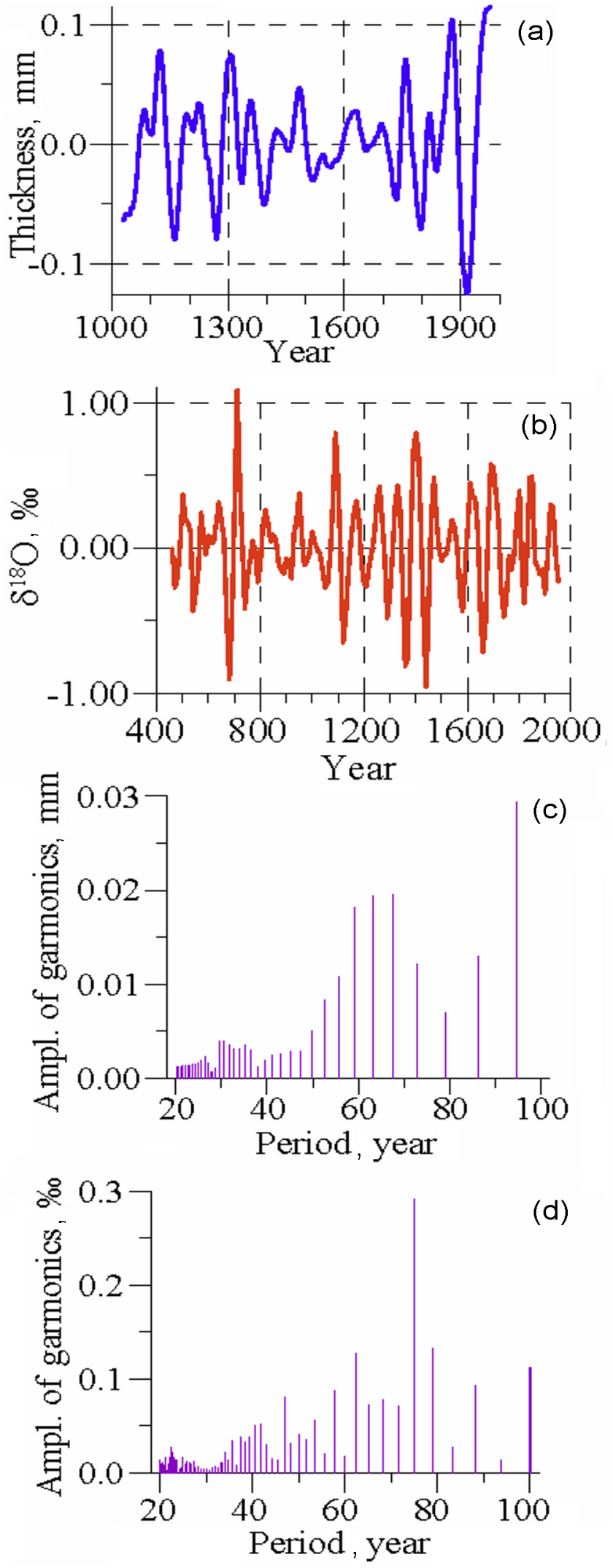

Figure 6. Multidecadal components of the: (a) tree's annual rings series in Australia, (b) $\delta^{18} \mathrm{O}$ content in ice cores of Mt. Kilimanjaro, (c, d) their spectra, respectively. series may be called as complex or composite polyphonic signals.

The obtained results, taking into account a large spatial distances between the displacement of stations which data were used (the east African coast, the west Australian coast, the Himalayan foothills) indicate the planetary nature of the studied oscillations. This is confirmed also by publications, e.g. [Baumgartner et al., 1992, Klyashtorin and Lyubushin, 2007 Schlesinger and Ramankutty, 1994. Tourre and White, 2006. Wang et al., 2005.

\section{Discussion}

As mentioned above, a number of authors relates $\sim 60 \mathrm{yr}$ monsoon variability with solar activity. Thus, it should also have $\sim 60$ yr component. To identify multidecadal oscillations in solar activity we used the Wolf number paleoreconstruction for the last $\sim 11,000$ yrs [Solanki et al., 2004].

Figure 7 shows the curve obtained by processing of this series segment from $1000 \mathrm{BC}$ to $1895 \mathrm{AD}$ by BMAF with 50-110 yrs band. On the general background are noticeable groups of dominating harmonics in the ranges of 42-46, 5565, 70 and 80-90 yrs (Figure 7); the latter refers to the Gleissberg cycle. Analogous result was obtained after a similar processing of a $2000 \mathrm{yr}$ series of sediments on the shelf of Pakistan (Figure 7 $)$. In its spectrum dominant groups are in the ranges 50-60, 70-80 and 90-100 yrs (Figure 7d).

Thus, these groups of oscillations with similar periods in the interdecadal monsoon variability which have been discussed above, including a group of oscillations forming $\sim 60$ yr cycle, should be searched in about the same ranges.

On the example of the field of annually averaged $P$ reanalysis data it can be shown that spatial dynamics of the Indian monsoon region (Figure 8a, Figure 8b) associated with $\mathrm{a} \sim 60$ yr oscillations in the first approximation can be reduced to a change in the size and location of the main areas of high and low $P$ values (being placed at about $30^{\circ} \mathrm{S}$ and $20-30^{\circ} \mathrm{N}$, respectively). As it is seen in Figure 8 ing the 1955-1965 ("winter" of the interannual $P$ values), low $P$ area forms a broad band from West Africa to Southeast Asia, extending southward to about $10^{\circ} \mathrm{S}$, and almost reaches the northern tip of Madagascar. A typical indicator of this process is the position of the $1009-1011 \mathrm{hPa}$ isobars. This interval can be referred to the negative IOD phase (see Figure 2a).

During the 1990-2001 ("summer" of the interannual $P$ values), on the contrary, increased the area of high pressure, extending its influence to the north of the equator and being particularly active along the Kenyan and Somalian coasts (Figure 8p). A low pressure area is weakened, divided into several local centers and in the Arabian Sea retreats to the coast of Pakistan and India. This interval can be referred to the positive phase of the IOD.

However, an average geographic location of the main pressure regions remains stable (Figure 8p).

Significant differences in the spatial-temporal structure of the interdecadal oscillations are observed in the fields of all parameters studied in the Earth sciences. From this work 

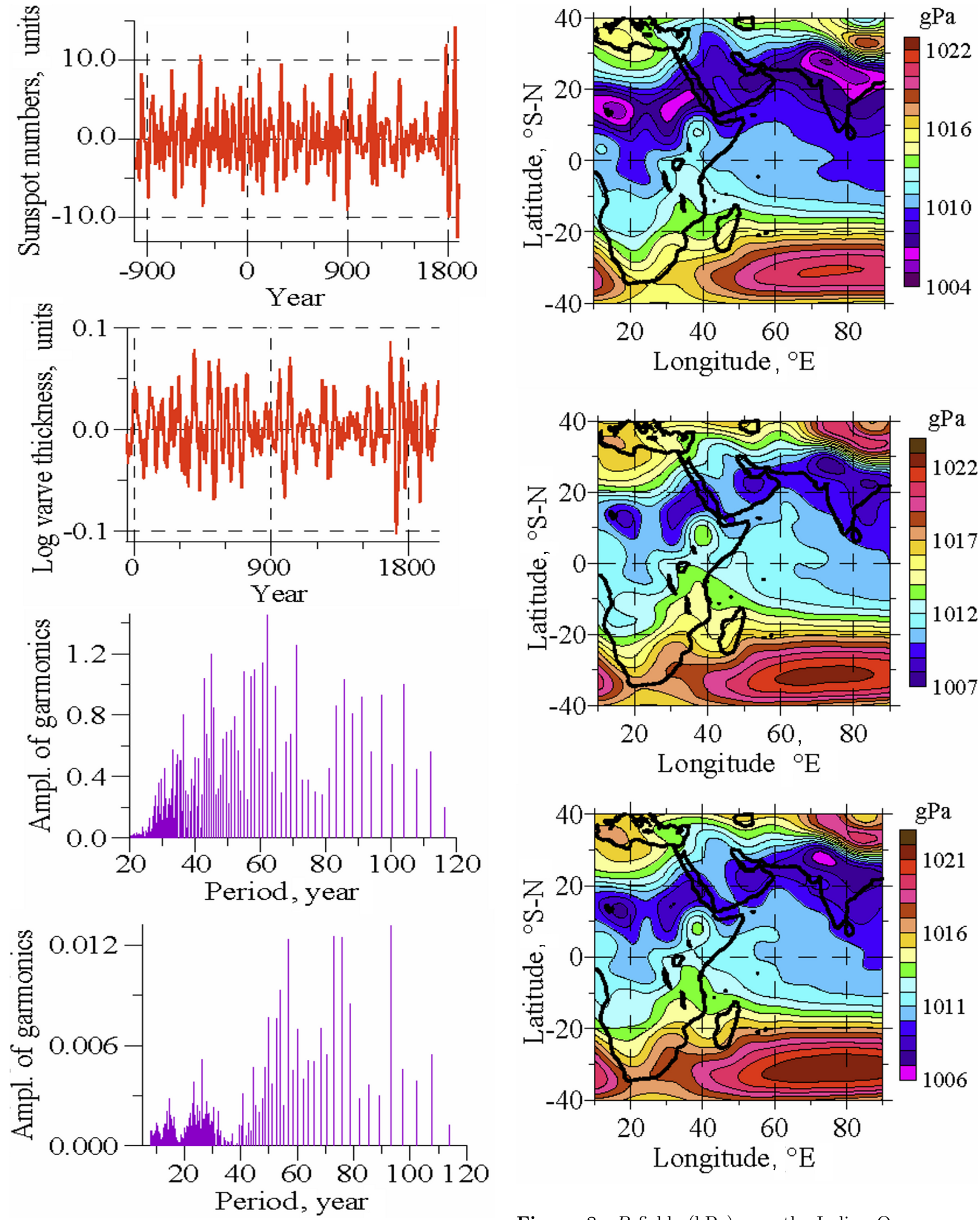

Figure 7. (a) segment of the Wolf number paleoreconstruction over the past 3000 yrs after BMAF processing, (b) segment of the sediment thickness on the shelf of Pakistan over the past 2000 yrs after BMAF processing, (c) spectrum of the (a)-series, (d) spectrum of the (b)-series.
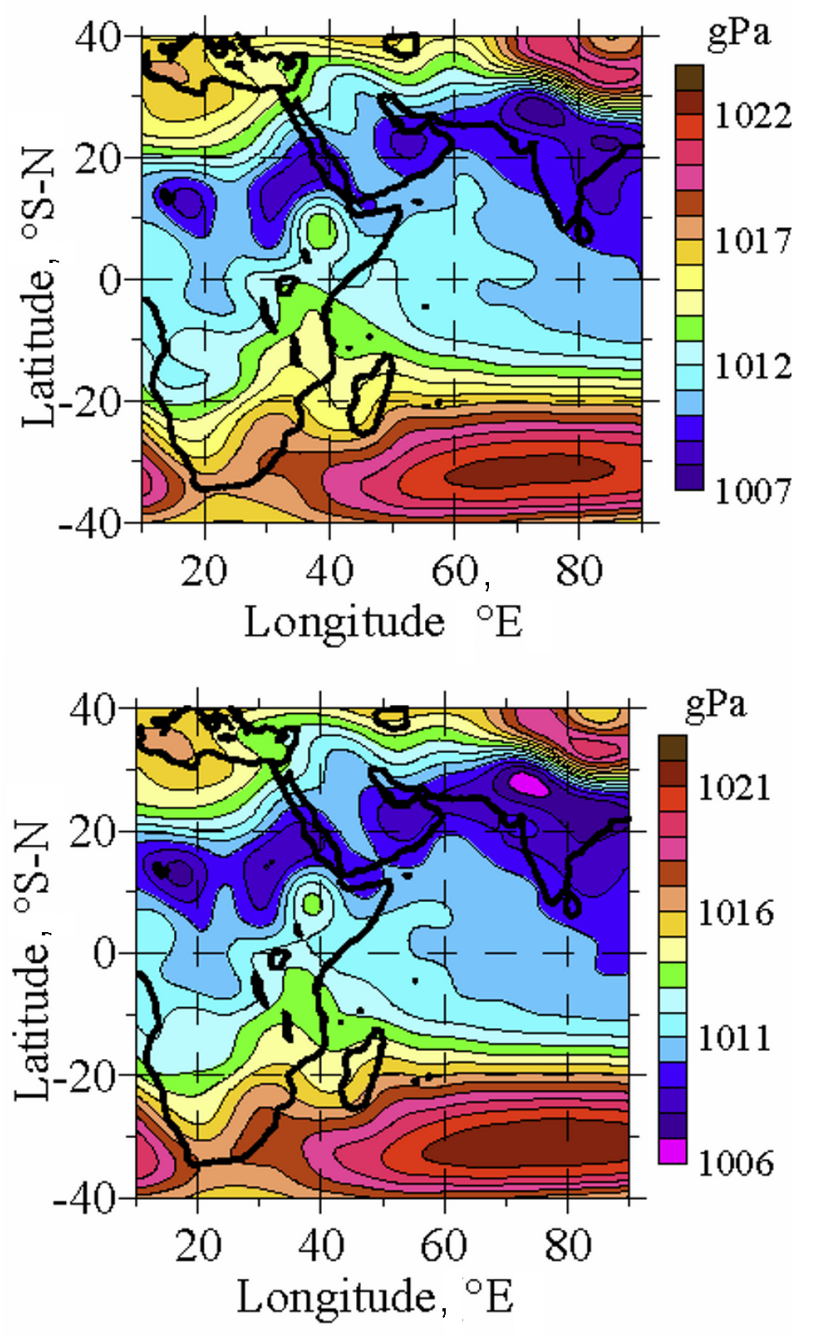

Figure 8. $P$ fields $(\mathrm{hPa})$ over the Indian Ocean area according to a reanalysis data: (a) averaged over 1955-1965 at relatively low values of the SAT, SST and negative IOD phase, (b) these fields averaged over 1990-2001 at relatively high values of SAT, SST and positive IOD phase, (c) these fields averaged over total reanalysis interval 1949-2009. 
and others listed in the references, it is clear that the Indian Ocean region in this regard is not an exception. It can be assumed that the formation and spatial dynamics of local areas of the averaged $P$ values presented in Figure 8 are interconnected and are largely a consequence of the existence of the general planetary field of orthogonal standing and traveling thermal waves (GPWF) and on the changes occurring in this field at interannual scales depending on the phases of the dominant cycles [Eremeev et al.,2012b] Tourre and White, 2006 White and Tourre, 2003.

It is advisable to explore the relations of regions with sustainable anomalies, for example, $P$ (including atmospheric centers of action) with the GPWF standing waves and time anomalies - with GPWF traveling waves. It is desirable to do the same with respect to various dipole structures in the atmosphere and in the ocean, including the IOD. The extent of the contribution of GPWF in the formation of these objects of research have yet to be estimated.

\section{Conclusions}

Significant role in the variability of the monsoon circulation regime of the Arabian Sea and Indian Ocean within the last two centuries are playing $\sim 60$ yr quasi-periodic oscillations of studied parameters.

They are complex composite signals due to presence in them of oscillations with nearby amplitudes and periods in the ranges of about $42-46,55-65$ and $70-75$ yrs. This results in expressed modulation of $\sim 60 \mathrm{yr}$ oscillations. Another their characteristic feature is a significant difference in phases for various areas of the Indian monsoon sub-system and the Asian monsoon in general. These properties of $\sim 60$ yr oscillations are consistently traced in data of various paleoreconstructions over the past 2000-5000 yrs.

In addition to the group of $\sim 60 \mathrm{yr}$ oscillations, groups of short-period ones with periods of $\sim 9-15$ and $22-25$ yrs, and the long-period $\geq 100 \mathrm{yrs}$, are also expressed in the interannual scales.

\section{References}

Abram, N. J., M. K. Gagan, Zh. Liu, H. S. Hantoro, M. T. McCulloch, B. W. Suwargadi (2007), Seasonal characteristics of the Indian Ocean Dipole during the Holocene epoch, Nature, 445, 299-302, doi:10.1038/nature05477

Agnihotri, R., K. Dutta, R. Bhushan, B. L. K. Somayajulu (2002), Evidence for solar forcing on the Indian monsoon during the last millennium, Earth and Planetary Sci. Lett., 198, 521-527, doi:10.1016/S0012-821X(02)00530-7

Baumgartner, T. R., A. Soutar, V. Ferreira-Bartrina (1992), Reconstruction of the history of Pacific sardine and Northern Pacific anchovy populations over the past two millennia from sediments of the Santa Barbara basin, CalCOFI (Calif. Coop. Fish. Investig.), No. 33, 24-40.

Berger, W. H., U. von Rad (2002), Decadal to millennial cyclicity in verves and turbidities from the Arabian Sea: hypothesis of tidal origin, Global and Planetary Change, 34, $313-325$
Buehring, C. (2001), Decadal to millennial cyclicity in verves and turbidities from the Arabian Sea: hypothesis of tidal origin, University of Kiel, Kiel.

Byshev, V. I., V. G. Neiman, Ju. A. Romanov, I. V. Serykh (2012), El Niño as consequence of global atmospheric oscillations in dynamics of the Earth climatic system, Transactions (Doklady) of the Russian Academy of Sciences, 446, No. 1, 89-94. (in Russian)

Eremeev, V. N., A. N. Jukov, N. E. Lebedev, S. A. Piontkovski, A. A. Sizov (2012a), Interannual fluctuations of the atmospheric pressure, sea surface temperature, and chlorophyll-a of the Arabian Sea, Int. J. Oceans and Oceanography, 6, No. 2, 83-93.

Eremeev, V. N., A. N. Zhukov, A. A. Sizov (2012b), Investigation into wave properties of the Atlantic surface temperature spatial variability on interannual scales, Issledovanie Zemli iz Kosmosa, 3, 12-23, doi:10.1134/S0001433812090046

Goswami, B. N. (2004), The Asian Monsoon: Interdecadal Variability, The Global Monsoon System: Research and Forecast, Report of the International Committee of the Third International Workshop on Monsoons (IWM-III), 2-6 November 2004, Hangzhou, China. Tropical Meteorology Research Programme (TMRP), Report No. 70 p. 47-71, University of Kiel, Kiel.

Goswami, B. N., M. S. Madhusoodanan, C. P. Neema, D. Sengupta (2006), A physical mechanism for North Atlantic SST influence on the Indian summer monsoon, Geophys. Res. Lett., 33, L02706, doi:10.1029/2005GL024803

Hamming, R. W. (1983), Digital Filters, 221 pp., PrenticeHall, Englewood Cliffs, N.J.

Hartmann, D. (1994), Global Physical Climatology, 411 pp., Academic, New York.

Klyashtorin, L. B., A. A. Lyubushin (2007), Cyclic Climate Changes and Fish Productivity, 224 pp., VNIRO (All Russian Institute Fisheries and Oceanography) Publishing, Moscow.

Li, T., B. Wang, C.-P. Chang, Y. Zhang (2003), A Theory for the Indian Ocean Dipole - Zonal Mode, J. Atm. Sci., 60, No. 17, 2119-2135.

Lobanov, V. A., V. E. Leonov (1990), Empirical verification of the justifiability of the generalized parameters of hydrometeorological series, Meteorology and Hydrology, No. 10, 106-113. (in Russian)

Loehle, C., N. Scafetta (2011), Climate Change Attribution Using Empirical Decomposition of Climatic Data, The Open Atmospheric Sci. J., 5, 74-86.

Mehta, V. M., K. M. Lau (1997), Influence of solar irradiance on the Indian monsoon - ENSO relationship at decadalmultidecadal time scales, Geophys. Res. Lett., 24, 159-162.

Monin, A. S., D. M. Sonechkin (2005), Oscillations of Climate According to Observation Data. Thriple Sun-Induced and Other Cycles, 191 pp., Nauka, Moscow. (in Russian)

Neiman, V. G., V. A. Burkov, A. D. Sherbinin (1997), Dynamics of the Indian Ocean Water, 232 pp., Scientific World, Moscow. (in Russian)

Pokrovsky, O. M. (2010), Climate Change Impact Factors Estimation by Data of Direct and Remote Sensing Measurements, Issledovanie Zemli iz Kosmosa, No. 5, 11-24. (in Russian)

Rao, S. A., et al. (2002), Interannual variability in the subsurface Indian Ocean with special emphasis on the Indian Ocean Dipole, Deep Sea Research-II, 49, No. 7-8, 1549-1572, doi:10.1016/S0967-0645(01)00158-8

Rayner, N. A., D. E. Parker, E. B. Horton, C. K. Folland, L. V. Alexander, D. P. Rowell, E. C. Kent, A. Kaplan (2003), Global analyses of sea surface temperature, sea ice, and night marine air temperature since the late nineteenth century, $J$. Geophys. Res., 108, No. D14, 4407, doi:10.1029/2002JD0026 70

Scafetta, N. (2010), Empirical evidence for a celestial origin of the climate oscillations and its implications, J. Atm. Sol.-Terr. Phys., 72, 951-970, doi:10.1016/j.jastp.2010.04.015

Schlesinger, M. E., N. Ramankutty (1994), An oscillation in the global climate system of period $65-70$ years, Nature, 367 , No. 6465, 723-726. 
Schneider, U., A. Becker, A. Meyer-Christoffer, M. Ziese, B. Rudolf (2010), Global Precipitation Analysis Products of the GPCC, GPCC, Deutscher Wetterdienst, Offenbach a. M., Germany.

Solanki, S. K., I. G. Usoskin, B. Kromer, M. Schessler, J. Beer (2004), An unusually active Sun during recent decades compared to the previous 11,000 years, Nature, 431, No. 7012, 1084-1087.

Sverdrup, H. U., M. W. Johnsona, R. H. Fleming (1942), The Oceans, Their Physics, Chemistry and General Biology, 1087 pp., Prentice-Hall, Englewood Cliffs, N.J..

Tourre, Y. M., W. B. White (2006), Global climate signals and equatorial SST variability in the Indian, Pacific and Atlantic oceans during the 20th century, Geophys. Res. Lett., 33, L06716.

Tsiropoula, G. (2003), Signatures of solar activity variability in meteorological parameters, J. Atm. Sol.-Terr. Phys., 65 469-482.
Vityazev, V. V. (2001),

Wavelet Analysis of Time Series, 58 pp., St.-Petersburg University Publishing House, St.Petersburg. (in Russian)

Wang, P., S. Clemens, L. Beaufort, P. Braconnot, G. Ganssen, Z. Jian, P. Kershaw, M. Sarnthein (2005), Evolution and variability of the Asian monsoon system: state of the art and outstanding issues, Quaternary Science Reviews, 24, 595629.

White, W. B., Y. M. Tourre (2003), Global SST/SLP waves during the 20th century, Geophys. Res. Lett., 30, No. 12, 53-1-53-4, doi:10.1029/2003GL017055

A. M. Chukharev, N. E. Lebedev, and A. N. Zhukov, Marine Hydrophysical Institute, Russian Academy of Sciences, Sevastopol, Russia. (nick_leb@mail.ru) 